\title{
NATURALLY OCCURRING PENTAOXYGENATED, HEXAOXYGENATED AND DIMERIC XANTHONES: A LITERATURE SURVEY*\#
}

\author{
V. Peres* \\ Departamento de Química - Universidade Federal de Viçosa - UFV - 36571-000 - Viçosa - MG \\ T. J. Nagem \\ Departamento de Química - Universidade Federal de Ouro Preto - UFOP - 35400-000 - Ouro Preto - MG
}

Recebido em 29/4/96; aceito em 16/10/96

\begin{abstract}
This review gives information on the chemical study of 71 pentaoxygenated, 11 hexaoxygenated and 9 dimeric and more complex xanthones naturally occurring in 7 families, 29 genus and 62 species of higher plants, and 11 described as fern and fungal metabolites. The value of these groups of substances in the connection with the pharmacological activity and the therapeutic use of some species is shown. The structural formulas of 23 isolated compounds and their distribution in the species studied are given.
\end{abstract}

Keywords: xanthone; pentaoxygenated xanthones; hexaoxygenated xanthones; dimeric xanthones; pharmacological activity; fungus; biosynthesis.

\section{INTRODUCTION}

Xanthones are secondary metabolites commonly occurring in a few higher plant families, fungi and lichen. Their high taxonomic value in Such families and their pharmacological properties have roused great interest ${ }^{31}$.

The symmetrical nature of the xanthone nucleus, coupled with its mixed biogenetic origin in higher plants necessitates that the carbons be numbered according to a biosynthetic convention. Carbons 1-4 are assigned to the acetate-derived ring A, and carbons $5-8$ to the shikimate-derived ring $\mathbf{B}^{24}$. The numbering system is based on xanthene-9-one as the basic skeleton ${ }^{62}$ and in cases where only ring $\mathbf{B}$ is oxygenated the lowest numbers are used, except in the biosynthetic discussion ${ }^{24}$.

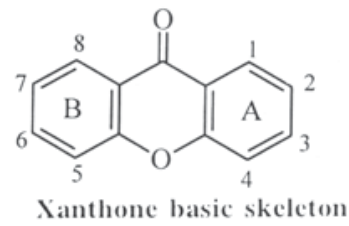

\section{CLASSIFICATION}

The Xanthones isolated so far may be classified into five major groups: simple oxygenated xanthones, xanthones glycosides, prenylated and related xanthones, xanthonolignoids and miscellaneous ${ }^{103}$. Simple pentaoxygenated, Simple hexaoxygenated and dimeric xanthones, as well as prenylated and related xanthones with the same degree of oxygenation are listed in this review (Tables 1-3)

\section{METHODS OF ISOLATION AND STRUCTURAL INVESTIGATION}

Xanthones are commonly separated by chromatography on silica gel, using different solvent mixtures ${ }^{72}$. Xanthones are also separated and identified by comparison with authentic samples by Thin-Layer Chromatography ${ }^{38}$ and High-Pressure Liquid Chromatography ${ }^{74,75}$. The structure of the simple oxygenated xanthones have been established mainly From the UV, IR, MS and NMR data of these compounds ${ }^{13,14,132,148}$

Xanthones can be detected by their colours in UV light with and without ammonia or by using a general phenolic spray ${ }^{72}$. The UV spectrum varies in a characteristic manner depending, on the oxygenation pattern and with the availability of a considerable; amount of data, assignments can be readily made. Besides use of $\mathrm{AlCl}_{3}$ shifts for chelated hydroxyl, sodium acetate, sodium hydroxide and boric acid shifts, considerable information of the position of hydroxyl groups in other locations can be obtained ${ }^{112,148}$

The use of infrared spectroscopy in xanthone chemistry is limited in detecting the carbonyl stretching frequency ${ }^{114,132}$. In special, effect of chelation on the infrared carbonyl frequency of hydroxy-xanthones may be useful in spectra of some substituted and extended xanthones ${ }^{39,137}$. The use of IR for detecting other functional groups, such as unchelated hydroxyl and methyl groups does not require comment ${ }^{132,135,136}$.

By introducing lichen samples in a mass spectrometer via a direct inlet system Santesson ${ }^{134}$ obtained mass spectra of the volatile lichen substaces. The method showed well suited for tentative identification of lichen xanthones ${ }^{134,136}$. Apart from discussion of the mass spectra of lichen xanthones, no systematic investigation of the electron-impact-induced fragmentation of xanthones appears to have been made, except by Arends et al in the study of electron-impact-induced fragmentation of monohydroxy- and monomethoxyxanthones ${ }^{14}$. Mass spectrometry has not heen applied extensively to the study of naturally occurring xanthones, but the MS data have been very valuable for a preliminary examination ${ }^{20}$.

The data obtained in proton magnetic resonance spectra should be of great value in characterizing and identifying, naturally occurring xanthones ${ }^{108}$. ${ }^{1} \mathrm{H}$ NMR spectroscopy has been used for determining the structure of substituents and for locating aromatic protons by comparison with reference data and

\footnotetext{
* Part of DS Thesis of autor, submited at Universidade Federal de Minas Gerais, UFMG.

\# “Trioxygenated Naturally Occurring Xanthones" - Phytochemistry, 1997, 44, 191; "Tetraoxygenated Naturally Occurring Xanthones" - Bull. Soc. Chim. France 1997, in press; "The Chemosystematic Significance of Xanthones in Gentianaceae, J. Ethnopharm. (submitted).
} 
by analysis of spin-spin coupling. A closer scrutiny of chemical shifts of the aromatic protons allows prediction of the oxygenation pattern 21 . There are detailed NMR results for this class of compounds ${ }^{159}$

${ }^{1} \mathrm{H}$ NMR and ${ }^{13} \mathrm{C}$ NMR are the most useful tools in structure elucidation of xanthones ${ }^{37}$. The ${ }^{13} \mathrm{C}$ NMR spectra of a great number of naturally occurring xanthones are reported and all chemical shifts assigned ${ }^{33,50,159}$. Hambloch and Frahm ${ }^{70}$ introduced a computer program nominated SEOX 1, which rapidly identifies unknown xanthones with the help of additivity rules that represents a remarkable facilitation in structure elucidation.

\section{BIOACTIVITIES OF XANTHONES}

The study of xanthones is interesting not only for the chemosystematic investigation but also from the pharmacological point of view. Xanthones posses an antidepressant action and an antitubercular activity, while xamthone glycosides have a depressant action. A choleretic, diuretic, antimicrobial, antiviral and cardiotonic action of some xanthones has also been established $76,88,151,152$. The inhibition of Type A and Type B monoamine oxidases by a number of xanthones have also been observed ${ }^{151,152}$.

Recently, the various bioactivities of xanthones cytotoxic and antitumour activity, anti-inflammatory activity, anti-fungal activity, enhancement of choline acetyltransferase activity and inhibition of lipid peroxidase have been revealed ${ }^{78}$. In 1994 Mehta et $a l^{110}$ reported the total synthesis of novel xanthone antibiotics Cervinomycins $\mathrm{A}_{1}$ and $\mathrm{A}_{2}$, with promising activity against anaerobic bacteria, mycoplasma and some gram positive bacteria and their structural novelty.

Over recent years, xanthones have emerged as a class of compounds possessing a broad spectrum of biological and pharmacological activities ${ }^{43,44}$. The pharmacological interest in xanthones is based on their inhibitory effect on mono-amine oxidase (MAO) as well as their cytotoxic and antitumour activity $^{23}$. In general, xanthones and their derivatives were shown to be effective as an allergy inhibitor and bronchodialator in treatment of asthma ${ }^{18}$

A series of isoprenylated xanthones isolated from moraceous plants showed interesting biological activities such as hypotensive effect, anti-rhinoviral activity, inhibition of the formation of some prostanoids and anti-tumor promoting activity ${ }^{71}$.

The actinoplanones, polycyclic xanthones isolated from culture broth of Actinoplanes sp showed strong antimicrobial activities against bacteria and the rice fungus as well as exhibited strong cytoloxicity against the cells and inhibitory action on DNA synthesis ${ }^{90}$. Fermentations of Penicillium glabrum produce a complex mixture of dimeric xanthones with potent CD4binding activity in an ELISA based on the binding of the monoclonal antibody anti- Leu 3 a to soluble recombinant CD4 ${ }^{161}$.

Xanthones, in spite of their restricted occurrence in the plant kingdom, are reported to posses antileukemic, antitumor, antiulcer, antimicrobial, antihepatotoxic, and CNS-depressant activities ${ }^{19}$.

\section{NATURAL SOURCE OF PENTAOXYGENATED,} HEXAOXYGENATED AND DIMERIC XANTHONES

The pentaoxygenated, hexaoxygenated and dimeric xanthones are described in this review as occurring in 7 families, 29 genera and 62 species of higher plants, one fern and two fungi species:

Genus Uvaria

Genus Alnus

Genus Croton

Genus Blackstonia

\section{Family Annonaceae}

$$
\text { - U. Kirkii }{ }^{154}
$$

Family Betulaceae

$$
\text { - A. glutinosa }{ }^{87}
$$

Family Euphorbiaceae

- C. californicus ${ }^{154}$

Family Gentianaceae

- B. perfoliata ${ }^{155}$
Genus Canscora

Genus Centaurium

Genus Chironia

Genus Erythraea

Genus Eustoma

Genus Frasera

Genus Gentiana

Genus Halenia

Genus Hoppea

Genus Ixanthus

Genus Swertia

Genus Tripterospermum

Genus Veratrilla

Genus Calophyllum

Genus Cratoxylum

Genus Garcinia

Genus Kielmeyera

Genus Mesua

Genus Ploiarium

Genus Psorospermum

Genus Vismia

Genus Cudrania

Genus Bredemeyera

Genus Monnina

Genus Polygala
- C. decussata ${ }^{36,54-57}$

- C. cachanlahuen ${ }^{157}$

C. erythraea ${ }^{23,86,111,115}$

C. linarifolium 119,120,121

C. littorale $^{23,156}$

- C. krebsii ${ }^{160}$

- E. centaurium ${ }^{153}$

- E. grandiflorum ${ }^{147}$

- F. albicaulis ${ }^{144}$

F. albomarginata 46

F. caroliniensis $^{143,144}$

F. speciosa ${ }^{46}$

F. tetrapetala ${ }^{7}$

- G. bellidifolia ${ }^{30,105}$

G. campestris $^{30,84}$

G. corymbifera ${ }^{107,133}$

G. germanica $^{30,85}$

G. ramosa $^{30,85}$

- H. asclepidea ${ }^{146}$

- H. campanulata77

- H. corniculata116,127

- $H$ elliptica ${ }^{42,149}$

- H. dichotoma ${ }^{58}$

- I. viscosus ${ }^{118}$

- S. bimaculata ${ }^{59}$

S. milensis ${ }^{99}$

S. tetrapetala ${ }^{8}$

S. purpurascens $^{9,60}$

S. lawii $^{59}$

S. paniculata $^{11}$

S. cordata $^{130}$

S. punicea $^{52}$

S. mussotii $^{73}$

S. iberica $^{41}$

S. chirata $^{102}$

S. macrosperma ${ }^{163}$

- T. lanceolatum ${ }^{97}$

- V. bailonii ${ }^{162}$

Family Guttiferae

- C. bracteatum ${ }^{142}$

- C. inophyllum ${ }^{79}$

- C. cochinchinense $e^{139}$

- G. livingstonei ${ }^{43}$

- K. rubriflora ${ }^{64}$

- M. ferrea $^{67}$

- P. alternifolium ${ }^{25}$

- P. febrifugum ${ }^{2,69}$

- V. guineensis ${ }^{29}$

Family Moraceae

- C. cochinchinesis ${ }^{34}$

Family Polygalaceae

- B. brevifolia ${ }^{117}$

- M. obtusifolia ${ }^{125}$

- P. macradenia ${ }^{45,145}$

P. nyikensis ${ }^{106}$

P. paenea ${ }^{113}$

P. tenuifolia ${ }^{51,80,82}$

P. triphylla ${ }^{53}$

P. spectabilis $^{12}$

P. virgata $^{22}$ 


$\begin{array}{lc} & \text { Fern } \\ \text { Genus Cystopterys } & - \text { C. Fragilis } \\ & \text { Fungi } \\ \text { Penicillium glabrum } & \\ \text { Actinoplanes } s p^{89,90} & \end{array}$

\section{USES OF PLANTS SOURCE OF PENTAOXYGENATED, HEXAOXYGENATED AND DIMERIC XANTHONES}

Among Calophyllum species (Guttiferae), C. inophyllum is the most widespread and has superior timber qualities in $\mathrm{Ma}$ laysia ${ }^{61}$. The balsam from the bark of $C$. inophyllum "Alexandrian Laurel" is called an "oleoresin" and used as a cicatrisant, whereas an infusion or decoction of the leaves has been traditionally used as an eye remedy in Asian medicine $^{78}$. Xanthones from $C$. inophyllum produces CNS depression in rats and mice ${ }^{24}$.

Canscora decussata Schult (Gentianaceae), an erect annual plant of height $0.6 \mathrm{~m}$, founds use in the Ayurvedic system of medicine in India for a variety of purposes. The roots are used as laxative, diuretic, for liver troubles, nerve tonic, in tuberculosis and fevers, while the aerial portions are used in insanity, epilepsy and nervous debility ${ }^{27,36}$. The extract of $C$. decussata Schult is used in the treatment of tuberculosis and of certain mental disorders in the Indian system of medicine ${ }^{55}$.

Centaurium linarifolium (Gentianaceae) is used in Spain folk medicine as a digestive, antipyretic, and a drug helpful in increasing blood circulation ${ }^{119}$. The botanical source of the Taiwan folk remedy "Hwang-jin-guey" is the root and stem of Cudrania cochinchinensis (Lour.) Kudo \& Masamune var. gerontogea (S. \& Z.) Kudo \& Masamune ${ }^{34}$. It was used in the treatment of neuralgia, rheumatics, hepatitis and contused wounds ${ }^{35}$. Plalt extracts obtained from genus Eustoma are used to treat various ailments including constipation, nervous debility, tuberculosis, fever, and anorexia ${ }^{147}$.

Mesua ferrea (Guttiferae) is commonly called ironwood in Malaya. The hard and durable trunk-wood is used widely in agricultural tools and vehicles in the south-east Asian countries ${ }^{40}$. From the expressed oil of its seeds had been isolated two crystaline antibiotic principles, mesuol and mesuone ${ }^{65}$. In contrast to mangiferin, which is reported to be CNS stimulant ${ }^{27}$, xanthones from M. ferrea produces CNS depression in rats and mice ${ }^{24}$.

Monnina obtusifola (Polygalaceae) is used in the folk medicine of Equador as an antifungal, antitumoural, antipyorrhea, antiseptic and as a skin cleanser ${ }^{125}$.

Polygala spectabilis DC (Polygalaceae), trivial name caamembeca, is a common shrub of the estuary of the Amazon and the coastal region of Pará State, where it is used in popular medicine as expectorant, and in the treatment of hemorrhoids and amoebal infection ${ }^{12}$. The roots of $P$. tenuifolia are used as an expectorant, tonic and sedative agent under the names "Onji" in Japan and "Yuan zhi" in China ${ }^{80,82}$. It is also effective in inhibiting congestive oedema in rats ${ }^{51}$.

Psorospermum febrifugum (Guttiferae) is a woody plant of tropical Africa which has been used as a febrifuge, a leprosy treatment, a poison antidote, and a purgative. An ethanolic extract of $P$. febrifugum was fractionated with antileukemic activity in vivo in the P388 lymphocytic leukemia in mice and in vitro in the $\mathrm{KB}$ cell culture system used as a guilde ${ }^{93}$. From the extract was isolated six compounds were found to exhibit significant in vitro cytotoxic activity against 9PS cells in culture and another exhibited both in vitro cytotoxic and in vivo antitumour activity ${ }^{1-3}$ One of these six xanthones exhibited significant cytoloxicity in the HT-29 human colon adenocarcinoma in vitro cell line ${ }^{4}$. In special, the xanthone Psorospermin, isolated from $P$. febrifugum exhibited cytotoxic and in vivo antitumour activity in the P388 mouse leukemia, mammary (CD), and colon (C6) models ${ }^{68}$.

Plants of the genus Swertia (Gentianaceae) have been used in traditional medicines for many years. Because these herbs taste extremely bitter and possess the ability to reduce fever, detoxify and act as choleretic and liver tonics, they have been mainly used for the treatment of hepatic and choleric and inflammatory diseases, such as hepatitis, cholecystitis, pneumonia, osteomyelitis, dysentery, scabies, spasm, pain and neurasthenia ${ }^{163}$.

Swertia cordata is a perennial herb widely distributed in the northern areas of Pakistan. The plant finds extensive usage in folk medicine as an alterative, febrifuge, and anthelmintic as well as a bitter tonic ${ }^{130}$. S. macrosperma is a medicinal plant used as febrifuge, poison antidote and stomach tonic by the indigenous population in the south-western part of China ${ }^{163}$. S. mileensis and $S$. mussoti are especialy efficaceous for acute viral hepatitis and some preparations have been produced industrially in China. Extracts of $S$. purpurescens Wall are very commonly used as a tonic and febrifuge in the indigenous system of medicine in India 9 .

Vismia guineensis (Guttiferae) is a small tree growing in West Tropical Africa whose roots and bark are used as a tropical remedy for skin diseases ${ }^{29}$.

\section{SYNTHESIS AND BIOSYNTHESIS OF XANTHONES}

Some authors have reported the preparation of hydroxyxanthones ${ }^{15,66,128,129,138,141}$ but the first xanthone synthesis was proposed by Kostanecki ${ }^{91,92}$ and the last by Ravi et al ${ }^{131}$, with a new route to xanthone synthesis and Vitale $e t$ al ${ }^{158}$ with a novel route for the preparation of xanthones and chromanones.

Polyoxygenated xanthones of potential therapeutic and taxonomic value have been synthesized by a number of methods ${ }^{5}$. From 1,3-Dibenzyloxy-5,6,7,8-tetramethoxyxanthone Aurell et $a l^{17}$ synthesized 1,3-Dihydroxy-5,6,7,8-tetramethoxyxanthone and 1-Hydroxy-3,5,6,7,8-pentamethoxy- xanthone. The 1,8-Dihydroxy-2,3,4,6-tetramethoxyxanthone has been synthesized by trifluoroacetic anhydride (TFAA) condensation. The 1,6-Dihydroxy-3,5,7,8-tetramethoxyxanthone has been synthesized by Friedel-Crafts acylation ${ }^{17}$.

The 1,3,4-Trimethoxy-6,7-methylenedioxyxanthone (isopolygalaxanthone-A) has been synthesized From 1,3-Dihydroxy6,7-metltylenedioxyxanthone by hydroxylation with alkaline persulphate followed by methylation. The 1-Hydroxy-3,4,7trimethoxyxanthone on two-stage oxidation affords 1,2-Dihydroxy-3,4,7-trimethoxyxanthone ${ }^{83}$.

The total synthesis of lichen xanthones ${ }^{150}$, synthesis of furanoxanthones ${ }^{122,123}$, synthesis of new xanthones ${ }^{126}$, a new one-step method ${ }^{124}$ and a general study for synthesis of polyxygenated xanthones are reported recently by Lin et $a l^{98}$.

The biosynthetic pathways to xanthones have been discussed in recent years. Initially these attempted to interrelate the observed oxygen pattern of natural xanthones and correlate them with recognized oxygenation patterns. In general it is seem that ring $\mathrm{A}$ and attached $\mathrm{CO}$ group are provided by the shikimic acid pathway whereas ring B arises via the acetate-malonate polyketide route ${ }^{5,16,148}$. Therefore Locksley et $a l^{100}$ reported the significance of Maclurin in xanthone biosynthesis and the biogenetic-type synthesis of xanthones from their benzophenone precursors ${ }^{101}$. Gottlieb $^{62,63}$ showed biogenetic proposals regarding xanthones and Bhanu et $a l^{26}$ related the biogenetic implications in the conversion of 4-phenilcoumarins into xanthones. More recently was reported the biosynthetic studies on Tajixanthone and Shamixanthone ${ }^{10}$.

Some xanthones in lower plants have been proved to be totally acetate derived, from seven acetate units ${ }^{28,109}$. However, the oxygenation patterns of all xanthones in higher plants suggest that these are formed by a mixed shikimate-acetate pathway. 
This involves the condensation of shikimate and acetate-derived moieties to form benzophenones or benzophenone-like intermediates which then react intramolecularly to form xanthones. Mechanisms for this intramolecular reaction have been postulated involving either direct phenol oxidative coupling ${ }^{96}$, quinone addition $^{49}$, dehydration between hydroxyl groups on the acetate and shikimate-derived rings ${ }^{104}$ or spirodienone formation and subsequent rearrangement to form the xanthone ${ }^{32,62}$.

About lichen and fungi biosynthesis it is important to say that the many secondary metabolites found in the lichen-forming fungi play a dominant role in the systematics of these organisms because of the extensive parallels with morphology and their clear ecological significance. Despite their common occurrence in a number of important genera, lichen xanthones have not featured prominently in the repertoire of lichen taxonomists for several reasons. Nevertheless with the availability of more sensitive methods of detection and synthetic materials for comparison these compounds have been effectively employed in recent systematic studies of lichens ${ }^{47,48,95}$.

Elix and $\mathrm{Crook}^{48}$ reported the unambiguous total synthesis of seventeen chlorine-containing derivatives of norlichexanthone, achieved by using the condensation of an appropriately substituted methyl or ethyl orsellinate and phloroglucinol or 2-chlorophloroglucinol in the key step.

\section{PENTAOXYGENATED, HEXAOXYGENATED, DIMERIC AND MORE COMPLEX XANTHONES}

The first naturally occurring pentaoxygenated xanthone is Corymbiferin (1,3,8-Trihydroxy-4,5-dimethoxyxanthone), isolated in 1950 from Gentiana corymbifera ${ }^{133}$. The first naturally occurring hexaoxygenated xanthone is 1,2,3,4,6,7-hexamethoxyxanthone, isolated in 1969 from Polygala macradenia ${ }^{45}$. The first dimeric naturally occurring xanthone is Chiratanin, isolated from Swertia chirata in $1987^{102}$. Till to date, a large number of these naturally occurring xanthones have been isolated from higher plants, ferns and fungi ${ }^{103}$.

The review by Roberts ${ }^{132}$ only refers to the natural occurrence of the pentaoxygenated xanthone Corymbiferin. The next review, by Afzal et al ${ }^{6}$ included 24 pentaoxygenated xanthones and only one hexaoxygenated xanthone isolated from higher plants.

The review by Sultanbawa ${ }^{148}$ included more 4 pentaoxygenated xanthones from tropical plants, isolated from different mentioned species. Seven years later, in a review of xanthones from Guttiferae, Bennett and Lee ${ }^{24}$ listed only one new pentaoxygenated xanthone from Guttiferae species. Finally, in a review by Mandal et al ${ }^{103} 23$ pentaoxygenated, 7 hexaoxygenated and 3 dimeric xanthones are listed. How demonstrated, by 1989 the number of characterized natural xanthones of this species had considerably increased. During the period 1950 end 1995 was presented in reviews approximately 49 naturally occurring xanthones of these species. In present review 102 of these compounds found in the literature are next listed (Tables 1-3).

Table 1. Pentaoxygenated naturally occurring xanthones.

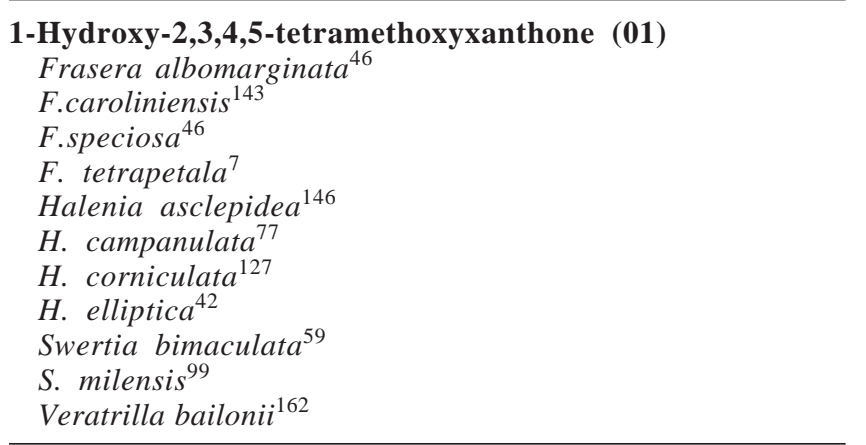

\section{Continuação Table 1}

1-Hydroxy-2,3,4,7-tetramethoxyxanthone (02)

Frasera albicaulis ${ }^{144}$

F. albomarginata ${ }^{46}$

F. caroliniensis $^{143}$

F. speciosa $^{46}$

Halenia asclepidea ${ }^{146}$

H. elliptica ${ }^{42}$

Swertia bimaculata ${ }^{59}$

S. tetrapetala ${ }^{8}$

1-Hydroxy-2,3,5,7-tetramethoxyxanthone (03) Halenia corniculata ${ }^{127}$

1-Hydroxy-3,4,5,8-tetramethoxyxanthone (04) Swertia purpurascens ${ }^{60}$

1-Hydroxy-3,4,7,8-tetramethoxyxanthone (05) Swertia lawii ${ }^{59}$

S. paniculata $^{11}$

S. purpurascens $^{60}$

1-Hydroxy-3,5,6,7-tetramethoxyxanthone (06) Canscora decussata ${ }^{56}$

Centaurium erythrae 86,111

Eustoma grandiflorum ${ }^{147}$

1-Hydroxy-3,5,7,8-tetramethoxyxanthone (07) Swertia cordata ${ }^{130}$

S. punicea $^{52}$

S. purpurescens $^{9}$

1-Hydroxy-3,6,7,8-tetramethoxyxanthone (08) Canscora decussata ${ }^{36}$

2-Hydroxy-1,3-dimethoxy-7,8-methylenedioxyxanthone (09) Polygala spectabilis ${ }^{12}$

2-Hydroxy-1,3,4,7-tetramethoxyxanthone (10)

Frasera albicaulis ${ }^{144}$

Swertia bimaculata ${ }^{59}$

6-Hydroxy-1,2,3,7-tetramethoxyxanthone (11) Polygala tenuifolia ${ }^{80,82}$

7-Hydroxy-1,2,3,4-tetramethoxyxanthone (12) Polygala macradenia ${ }^{45}$

7-Hydroxy-1,8-dimethoxy-2,3-methylenedioxyxanthone (13) Bredemeyera brevifolia ${ }^{117}$

1,2-Dihydroxy-3,4,5-trihydroxyxanthone (14) Halenia elliptica ${ }^{149}$

1,3-Dihydroxy-2,4,7-trimethoxyxanthone (15) Frasera tetrapetala ${ }^{7}$

1,3-Dihydroxy-4,5,8-trimethoxyxanthone (16) Swertia bimaculata $^{59}$

1,3-Dihydroxy-4,7,8-trimethoxyxanthone (17) (Methyllanceolin)

Tripterospermum lamceolatum ${ }^{97}$

1,3-Dihydroxy-5,6,7-trimethoxyxanthone (18) Cystopterys fragilis ${ }^{81}$

1,4-Dihydroxy-2,3,7-trimethoxyxanthone (19) Swertia bimaculata ${ }^{59}$

Veratrilla baillonii ${ }^{162}$

1,4-Dihydroxy-2,5,6-trimethoxyxanthone (20) Alnus glutinosa ${ }^{87}$

1,5-Dihydroxy-2,3,7-trimethoxyxanthone (21) Halenia elliptica ${ }^{149}$

1,6-Dihydroxy-3,5,7-trimethoxyxanthone (22) Polygala tenuifolia ${ }^{80}$

1,7-Dihydroxy-2,3,4-trimethoxyxanthone (23) Frasera speciosa ${ }^{46}$ Halenia campanulata ${ }^{77}$ 
Continuação Table 1

Polygala virgata ${ }^{22}$

1,7-Dihydroxy-3,4,8-trimethoxyxanthone (24)

Bredemeyera brevifolia ${ }^{117}$

B. floribunda ${ }^{140}$

Swertia mussotii ${ }^{73}$

1,7-Dihydroxy-3,5,6-trimethoxyxanthone (25) Canscora decussata ${ }^{55,56}$

Polygala nyikensis ${ }^{106}$

1,7-Dihydroxy-3,5,8-trimethoxyxanthone (26) Swertia cordata ${ }^{130}$

1,8-Dihydroxy-2,3,6-trimethoxyxanthone (27) Ixanthus viscosus ${ }^{118}$

1,8-Dihydroxy-2,3,7-trimethoxyxanthone (28) Calophyllum bracteatum ${ }^{142}$

1,8-Dihydroxy-2,3,8-trimethoxyxanthone (29) Calophyllum bracteatum ${ }^{142}$

1,8-Dihydroxy-2,4,6-trimethoxyxanthone (30) Swertia punicea ${ }^{52}$

1,8-Dihydroxy-3,4,5-trimethoxyxanthone (31)

(3-Methylcorymbiferin)

Gentiana corymbifera ${ }^{107}$

1,8-Dihydroxy-3,4,6-trimethoxyxanthone (32) Centaurium linarifolium ${ }^{121}$ Erythraea centaurium ${ }^{153}$

1,8-Dihydroxy-3,6,7-trimethoxyxanthone (33) Canscora decussata ${ }^{36}$

3,6-Dihydroxy-1,7,8-trimethoxyxanthone (34) Mesua ferrea ${ }^{67}$

3,8-Dihydroxy-1,2,4-trimethoxyxanthone (35) Psorospermum febrifugum ${ }^{69}$

6,8-Dihydroxy-1,2,3-trimethoxyxanthone (36) Polygala tenuifolia ${ }^{51}$

6,8-Dihydroxy-1,2,4-trimethoxyxanthone (37) Polygala tenuifolia ${ }^{51}$

1,2,3-Trihydroxy-7,8-dimethoxyxanthone (38)

(Swertiaiberin)

Swertia iberica ${ }^{41}$

1,3,5-Trihydroxy-6,7-dimethoxyxanthone (39) Canscora decussata ${ }^{54}$

1,3,6-Trihydroxy-2,5-dimethoxyxanthone (40) Monnina obtusifolia ${ }^{125}$

1,3,6-Trihydroxy-2,7-dimethoxyxanthone (41) (Onjixanthone II)

Bredemeyera floribunda $a^{140}$

Polygala tenuifolia ${ }^{80}$

1,3,6-Trihydroxy-7,8-dimethoxyxanthone (42) Mesua ferrea ${ }^{67}$

1,3,7-Trihydroxy-4,8-dimethoxyxanthune (43) Bredemeyera floribunda ${ }^{140}$

1,3,7-Trihydroxy-5,6-dimethoxyxanthone (44) Cansorra decussata ${ }^{55,56}$

1,3,8-Trihydroxy-2,6-dimethoxyxanthone (45) Ixanthus viscosus ${ }^{118}$

1,3,8-Trihydroxy-4,5-dimethoxyxanthone (46)

(Curymbiferin = 4,5-Di-O-methylcorymbin)

Gentiana bellidifolia ${ }^{30}$

G. Campestris ${ }^{30}$

G. corymbifera ${ }^{133}$

G. germanica $^{30,85}$

G. ramosa $^{30,85}$
Continuação Table 1

1,3,8-Trihydroxy-4,7-dimethoxyxanthone (47)

(4,7-Dimethoxybellidifolin $=4,7-\mathrm{Di}-\mathrm{O}$-methylbellidifolin) Gentiana bellidifolia ${ }^{30,105}$

1,3,8-Trihydroxy-6,7-dimethoxyxanthone (48) Canscora decussata ${ }^{36}$

1,4,8-Trihydroxy-3,7-dimethoxyxanthone (49)

(Lanceolin)

Tipterospermum lanceolatum ${ }^{97}$

1,5,6-Trihydroxy-3,7-dimethoxyxanthone (50) Canscora decussata ${ }^{54}$

1,5,7-Trihydroxy-3,6-dimethoxyxanthone (51) Canscora decussata ${ }^{54}$

1,5,8-Trihydroxy-3,4-dimethoxyxanthone (52) Gentiana campestris ${ }^{84}$

1,6,7-Trihydroxy-2,3-dimethoxyxanthone (53) Bredemoyera brevifolia ${ }^{117}$

1,6,7-Trihydroxy-3,5-dimethoxyxanthone (54) Canscora decussata 55,56 Hoppea dichotoma ${ }^{58}$

2,3,8-Trihydroxy-1,7-dimethoxyxanthone (55) Kielmeyera rubriflora ${ }^{64}$

1,3,5,6-Tetrahydroxyxanthone-7-methoxyxanthone (56)

(Caloxanthone E) Calophyllum inophyllum ${ }^{79}$

1,3,5,6,7-Pentahydroxyxanthone (57) Canscora decussata ${ }^{55}$

$\mathbf{1 , 3 , 6 , 7 , 8 - P e n t a h y d r o x y x a n t h o n e ~ ( 5 8 ) ~}$ Canscora decussata ${ }^{36}$

1-Methoxy-2,3,6,7-dimethylenedioxyxanthone (59) Polygala macradenia ${ }^{45}$ P. triphylla ${ }^{53}$

1-Methoxy-2,3,7,8-dimethylenedioxyxanthone (60) Bredemeyera brevifolia ${ }^{117}$

1,2,3-Trimethoxy-6,7-methylenedioxyxanthone (61)

(Polygalaxanthone A)

Polygala macradenia ${ }^{45,145}$

P. paenea ${ }^{113}$

1,2,3-Trimethoxy-7,8-methylenedioxyxanthone (62) Polygala spectabilis ${ }^{12}$

1,7,8-Trimethoxy-2,3-methylenedioxyxanthone (63) Bredemeyera brevifolia ${ }^{117}$

1,2,3,4,5-Pentamethoxyxanthone (64) Frasera albicaulis ${ }^{144}$

1,2,3,4,7-Pentamethoxyxanthone (65)

(Pulygalaxanthone B) Polygala paenea ${ }^{113}$

1,2,3,5,8-Pentamethoxyxanthone (66) Frasera carolinensis ${ }^{144}$

1,2,3,6,7-Pentametlurxyxanthone (67) Polygala tenuifolia ${ }^{80,82}$

1,2,3,7,8-Pentamethoxyxanthone (68) Polygala spectabilis ${ }^{12}$

6-Hydroxyisocadensin F (69) Psorospermum febrifugum 2

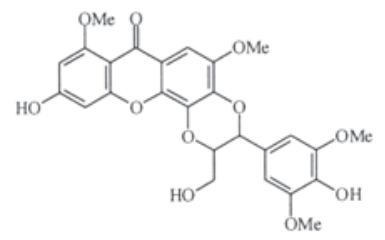

(69) 
Continuação Table 1

Gerontoxanthone D (70)

Cudrania cochinchinensis ${ }^{34}$

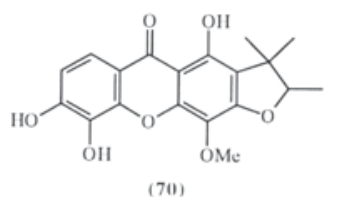

Xanthone $\mathbf{V}_{\text {2a }}$ (71)

Vismia guineensis ${ }^{29}$

Xanthone $\mathbf{V}_{\mathbf{2}}(\mathbf{7 2})$

Vismia guineensis ${ }^{29}$

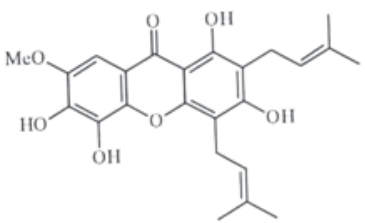

(71)

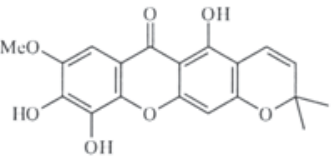

(72)
Table 2. Hexaoxygenated naturally occurring xanthones.

1-Hydroxy-3,5,6,7,8-pentamethoxyxanthone (73)

(Eustomin)

Centaurium erythraea ${ }^{23,86}$

C. linarifolium $^{120}$

C. littorale $^{23,156}$

Chironia krebsii ${ }^{160}$

Eustoma grandiflorum ${ }^{147}$

1,3-Dihydroxy-2,5,6,7-tetramethoxyxanthone (74) Bredemeyera brevifolia ${ }^{117}$

1,6-Dihydroxy-2,3,4,8-tetramethoxyxanthone (75) Halenia corniculata ${ }^{116}$

1,6-Dihydroxy-3,5,7,8-tetramethoxyxanthone (76) Centaurium linarifolium ${ }^{119,121,160}$

1,7-Dihydroxy-2,3,4,5-tetramethoxyxanthone (77) Halenia elliptica ${ }^{149}$

H. corniculata ${ }^{116}$

1,8-Dihydroxy-2,3,4,6-tetramethoxyxanthone (78)

Centaurium cachanlahuen ${ }^{157}$

C. Linarifolium ${ }^{119,121}$

C. erythraea ${ }^{111}$

Erithraea centaurium ${ }^{153}$

1,8-Dihydroxy-3,5,6,7-tetramethoxyxanthone (79)

(8-Desmethyleustomin)

Blackstonia perfoliata ${ }^{155}$

Centaurium erythraea ${ }^{23,86,115}$

C. littorale 23,156

Chironia krebsii ${ }^{160}$

1,3,8-Trihydroxy-2,4,6-trimethoxyxanthone (80) Centaurium linarifolium ${ }^{121}$

1,6,8-Trihydroxy-3,5,7-trimethoxyxanthone (81) Chironia krebsii ${ }^{160}$

1,2,3,4,6,7-Hexamethoxyxanthone (82)

Cansora decussata 57

Croton californicus ${ }^{154}$

Polygata macradenia ${ }^{45}$

Uvaria kirkii ${ }^{154}$

$\mathbf{1 , 3 , 5 , 6 , 7 , 8 , - H e x a m e t h o x y x a n t h o n e ~ ( 8 3 ) ~}$

Canscora decussata ${ }^{57}$

Swertia chirata ${ }^{102}$
Euxanmodin B (86)

Ploiarium alternifolium ${ }^{25}$

Table 3. Dimeric and more complex naturally occurring xanthones

\section{Ploiarixanthone (84) \\ Ploiarium alternifolium ${ }^{25}$}

Euxanmodin A (85)

Ploiarium alternifolium ${ }^{25}$

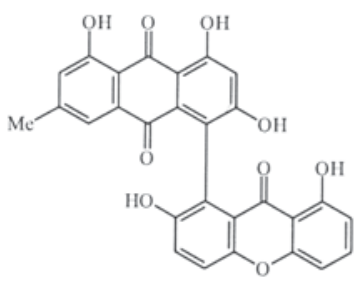

(x5)

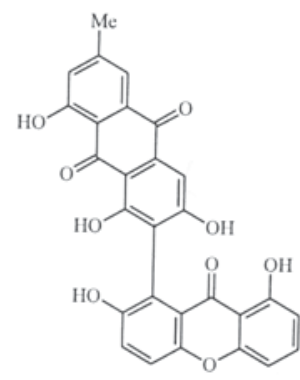

(x6)

Chiratanin (87)

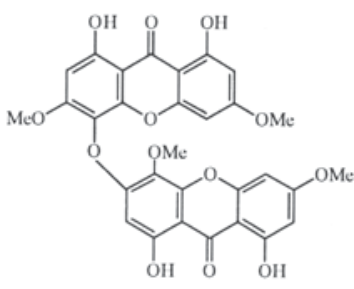

(87)

Swertiabisxanthone I (88) Swertia macrosperma ${ }^{163}$

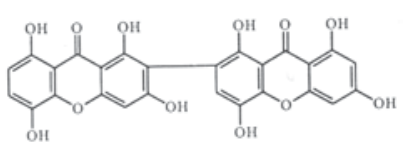

Cratoxyxanthone (89)

Cratoxylum cochinchinense ${ }^{13}$

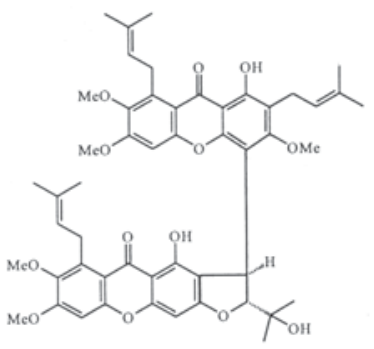

(89) 


\section{Continuação Table 3}

\section{Garcilivin B (90) \\ Garcinia livingstonei ${ }^{43}$}

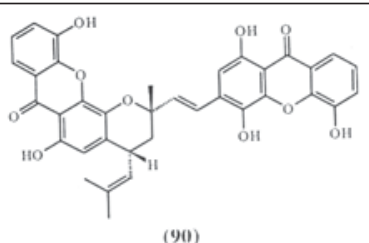

Garcilivin A (91)

Garcinia livingstonei ${ }^{43}$

Garcilivin C (92)

Garcinia livingstonei ${ }^{43}$

\section{Xanthone 411F \\ or Vinaxanthone (93)}

Penicillium glabrum $^{161}$

\section{Xanthone 411P (94)}

Penicillium glabrum $^{161}$

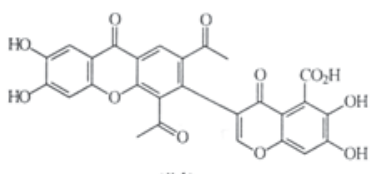

(9)

\section{Xanthone 411J (95)}

Penicillium glabrum $^{161}$

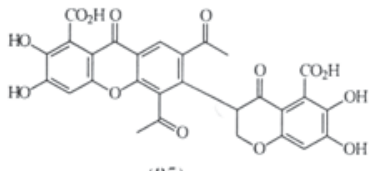

Actinoplanone A (96)

Actinoplanes $\mathrm{sp}^{89}$

Actinoplanone B (97)

Actinoplanes $\mathrm{sp}^{89}$
Continuação Table 3
Actinoplanone C (98)

Actinoplanes $\mathrm{sp}^{90}$

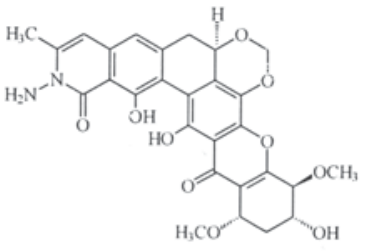

(9)

Actinoplanone D (99) Actinoplanes $\mathrm{sp}^{90}$

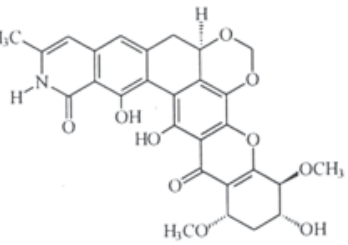

(99)

Actinoplanone E (100) Actinoplanes $\mathrm{sp}^{90}$

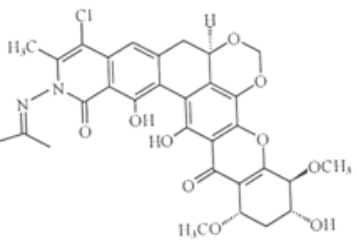

$(100)$

Actinoplanone F (101) Actinoplanes $\mathrm{sp}^{90}$

Actinoplanone $\mathbf{G}$ (102) Actinoplanes $\left.\mathrm{sp}^{9(}\right)$

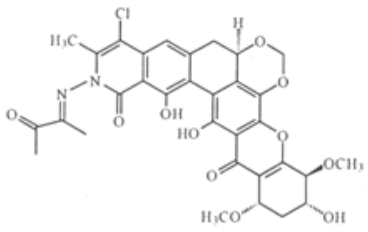

(101)

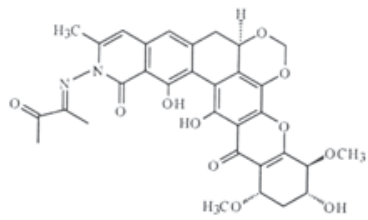

(102)

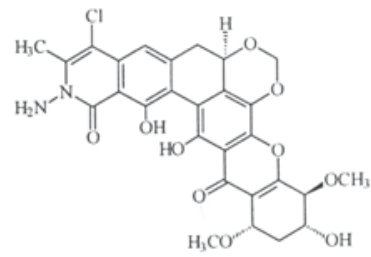

(96)

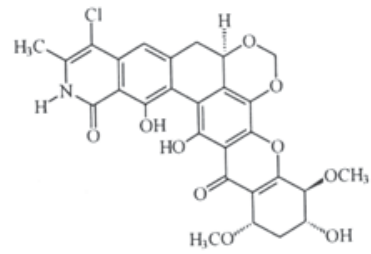

(97)

\section{ACKNOWILEDGMENTS}

The present work was supported by a grant from CAPES (Brasília-DF).

\section{REFERENCES}

1. Abou-Shoer, M.; Boettner, F. E.; Chang, C. J.; Cassady, J. M.; Phytochemistry 1988, 27, 2795.

2. Ahou-Shoer, M.; Habib, A. A.; Chang, C. J.; Cassady, J. M.; Phytochemistry 1989, 28, 2483.

3. Abou-Shoer, M.; Suwanborirux, K.; Chang, C.J.; Cassady, J. M.; Tetrahedron Let. 1989, 30, 3385.

4. Abou-Shoer, M.; Suwanborirux, K.; Habib, A. A. M.; Chang, C. J.; Cassady, J. M.; Phytochemistry 1993, 34, 1413.

5. Afzal, M.; Al-Hassan, J. M.; Helerocycles 1980, 14, 1173. 
6. Afzal, M ; Al-Hassan, J. M.; Al-Masad, F. N.; Heterocycles 1979, 12, 269.

7. Agata, I.; Nakaya, Y.; Nishibe, S.; Hisada, S.; Kimura, K.; Yakugaku Zasshi 1984, 104, 418.

8. Agata, I.; Sekizaki, H.; Sakushima, A.; Nishibe, S.; Hisada, S.; Kimura, K.; Yakugaku Zassh 1981, 101, 1067.

9. Ahmad, S.; Ikram, M.; Khan, I.; Galbraith, M. N.; Phytochemistry 1973, 12, 2542.

10. Ahmed, S. A.; Bardshiri, E.; McIntyre, C. R.; Simpson, T. J.; Aust. J. Chem. 1992, 45, 249.

11. Anand, P.; Basumatary, P. C.; Ghosal, S.; Handa, S. S.; Planta Med. 1982, 45, 61.

12. Andrade, C. H. S.; Braz Filho, R.; Gottlieb, O. R.; Silveira, E. R.; J. Nat. Prod. 1977, 40, 344.

13. Arends, P.; Helboe, P.; Acta Chem. Scand. 1972, 26, 4180.

14. Arends, P.; Helboe, P.; Moller, J.; Org Mass Spectrom. 1973, 7, 667.

15. Atkinson, H.; Heilbron. I. M.; J. Chem. Soc. 1926, 2688.

16. Atkinson, J. E.; Lewis, J. R.; J. Chem. Soc.(C) 1969, 281.

17. Aurell, M. J.; Gil, S.; Sanz, V.; J. Nat. Prod. 1989, 52, 852.

18. Balasubramanian, K.; Rajagopalan, K.; Phytochemistry 1988, 27, 1552.

19. Banerji, A.; Deshpande, A. D.; Prabhu, B. R.; Pradhan, P.; J. Nat. Prod. 1994. 57, 396.

20. Barnes, C.S.; Occolowitz, J. L.; Aust. J. Chem. 1964. 17, 975.

21. Barraclough, D.; Locksley, H. D.; Scheinmann, F.; Magalhães, M.T.; Gottlieb, O. R.; J. Chem. Soc.(B) 1970, 603.

22. Bashir, A.; Hamburger, M.; Msonthi, J. D.; Hostettmann, K.; Phytochemistry 1992, 31, 309.

23. Beerhues, L.; Berger,U.; Phytochemitry 1994, 35, 1227.

24. Bennett, G. J.; Lee, H. H. ; Phytochemistry 1989, 28. 967.

25. Bennett, G. J.; Lee, H. H.; Lee, L. P.; J. Nat. Prod. 1990, 53, 1463.

26. Bhanu, S.; Saroja, T.; Seshadri, T. R.; Mukerjee, S. K. Indian J. Chem. 1972, 10, 577.

27. Bhattacharya, S. K.; Ghosal, S.; Chaudhuri, R. K.; Sanyal, A. K.; J. Pharm. Sci. 1972, 61, 1838.

28. Birch, A. J.; Baldas, J.; Hlubucek, J. R.; Simpson, T. J.; Westerman, P. W.; J. C. S. Perkin I 1976, 898.

29. Botta, B.; Delle-Monache, G.; Delle-Monache, F.; Bettolo, G. B. M.; Menichini, F.; Phytochemistry 1986, 25, 1217.

30. Carbonnier, J.; Massias, M.; Molho, D.; Bull. Mus. natn. Hist. nat; Paris, $3^{\mathrm{e}}$ sér.; 504 (Sc. phys. chim.) 1977, 13, 23.

31. Cardona, M. L.; Fernandez. M. I.; Pedro, J. R.; Serrano, A.; Phytochemistry 1990, 29, 3003.

32. Carpenter, I.; Locksley, H.D.; Scheinmann, F.; Phytochemistry 1969, 8, 2013.

33. Castelão J R, J. F.; Gottlieb, O. R.; Lima, R. A.; Mesquita, A. A. L.; Gottlieb, H. E.; Wenkert, E.; Phytochemistry 1977, 16, 735.

34. Chang, C. H.; Lin, C. C.; Hattori, M.; Namba, T.; Phytochemistry 1989, 28, 595.

35. Chang, C. H.; Lin, C. C.; Hattori, M.: Namba, T.; J. Ethnopharm. 1994, 44, 79.

36. Chaudhuri, R. K.; Ghosal, S.; Phytochemistry 1971, 10, 2425.

37. Chaudhuri, R. K.; Zymalkowski, F.; Frahm, A. W.; Tetralredron 1978, 34, 1837.

38. Chawla, H. M.; Chibber, S. S.; khera, U.; J. Chromatogr. 1975, 111, 246.

39. Chawla, H. M.; Chibber, S. S.; Seshadri, T. R.; Proc. Indian Acad. Sci. 1973, 141.

40. Chow, Y. L.; Quon, H. H.; Phytochemistry 1968, 7, 1871.

41. Denisova, O. A.; Glyzin, V. I.; Patudin, A. V.; Fesenko, D. A.; Chem. Nat. Compds 1980, 2, 145.

42. Dhamana, H.; Garg, H. S.; Phytochemistry 1989, 28, 2819.

43. Diserens, I. S.; Hamburger, M.; Rogers, C.; Hostettmann, K.; Phytochemistry 1992, 31, 3589.
44. Diserens, I.S.; Rogers, C.; Sordat, B.; Hostettmann. K.; Phytochemistry 1992, 31, 313.

45. Dreyer, D. L.; Tetrahedron 1969, 25, 4415.

46. Dreyer, D. L.; Bourell, J. H.; Phytochemistry 1981, 20. 493.

47. Elix, J. A.; Crook, C. E.; The Bryologist 1992, 95, 52.

48. Elix, J. A.; Crook, C. E.; Jiang, H.; Zhi-Ning, Z.; Aust. J. Chem. 1992, 45, 845.

49. Ellis, R. C.; Whalley, W. B.; Ball, K.; Chem. Comm. 1967, 803.

50. Frahm, A. W.; Chaudhuri, R. K.; Tetrahedron 1979, 35, 2035.

51. Fujita, T.; Liu, D. Y.; Ueda, S.; Takeda, Y.; Phytochemistry 1992, 31, 3997.

52. Fukamiya. N.; Okano, M.; Kondo, K.; Tagahara K.; J. Nat. Prod. 1990, 53. 1543.

53. Ghosal, S.; Basumatari, P. C.; Banerjee, S.; Phytochemistry 1981, 20, 489.

54. Ghosal, S,: Biswas, K.; Chaudhuri, R. K.; J. Chem. Soc. Perkin I 1977, 1597.

55. Ghosal, S.; Chaudhuri, R. K.; J. Pharm. Sci, 1975, 64, 888.

56. Ghosal, S.; Chaudhuri, R. K.; Markham, K. R.; J. Chem. Soc. Perkin I 1974, 2538.

57. Ghosal, S.; Chaudhuri, R. K.; Nath, A.; J. Indian Chem. Soc 1971, 48, 589.

58. Ghosal, S.; Jaiswal, D. K.; Biswas, K.; Phytochemistry 1978, 17, 2119.

59. Ghosal, S.; Sharma, P. V.; Chaudhuri, R. K.; Phytochemistry 1975, 14, 2671

60. Ghosal, S.; Sharma, P. V.; Chaudhuri, R. K.: Bhattacharya, S. K.; J. Pharm. Sci. 1975, 64, 80.

61. Goh, S. H.; Jantan, I.; Phytochemistry 1991, 30, 366.

62. Gottlieh, O. R.; Phytochemistry 1968, 7, 411.

63. Gottlieh, O. R.;Magalhães, M. T.; An. Acad. Brasileira de Ciência 1966, 38, 439.

64. Gottlieh, O. R.; Mequita, A. A. L.; Nagem, T. J.; Phytochemistry 1971, 10, 2253.

65. Govindachari, T. R.; Pai, B. R.; Subramaniam, P. S.; Rao, U. R.; Mulhukumaraswamy, N.; Tetrahedron 1967, 23. 243.

66. Grover, P. K.; Shah, G. D.; Shah, R. C.; Xanthones. Part IV. J. Chem. Soc. 1955, 3982.

67. Gunasekera, S. P.; Ramachandran, S.; Selliah, S. S.; Sultanbawa, M. U. S.; J. Chem. Soc. Perkin I 1975, 2447.

68. Habib, A. M.; Ho, D. K.; Masuda, S.; McCloud, T.; Reddy, K. S.; Abou Shoer, M.; McKenzie, A.; Byrn, S. R.; Chang. C. J.; Cassady, J. M.; J. Org. Chem. 1987, 52, 412.

69. Habib, A. M.; Reddy, K. S.; McCloud, T.G.; Chang, C. J.; Cassady, J. M.; J. Nat. Prod. 1987, 50, 141.

70. Hambloch, H.; Frahm, A.W.; Tetrahedron 1980, 36, 3273.

71. Hano. Y.: Okamoto, T.; Nomura, T.; Momose. Y.; Heterocycles 1990, 31, 1345.

72. Harborne, J. B.; Phytochemical Methods. London, Chapman and Hall, 1973, 278p.

73. Hongfa, S.; Jingye, D.; Zhiwu Xuebao 1981, 23, 464.

74. Hostettmann, K.; Guillarmod, A. J.; J. Chrom. 1976, 124, 381.

75. Hostettmann, K.; McNair, H. M.; J. Chrom. 1976, 116, 201.

76. Hostettmann, K.; Wagner, H.; Xanthone Glycosides. Phytochemistry 1977. 16, 821.

77. Iglesias, M. C. R.; Marston, A.; liostettmann, K.; Phytochemistry 1992, 31, 1387.

78. Iinuma, M.; Tosa, H.; Tanaka, T.; Yonemori, S.; Phytochemistry 1994, 35, 527.

79. Iinuma. M.; Tosa, H.; Tanaka. T.; Yonemori, S.; Phytochemistry 1995, 38, 725 .

80. Ikeya, Y.; Sugama, K.; Okada, M.; Mitsuhashi, H.; Phytochemistry 1991, 30, 2061. 
81. Imperato, F.; Phytochemistry 1991, 30, 3839.

82. Ito, H.; Taniguchi, H.; Kita, T.; Matsuki, Y.; Tachirawa, E.; Fujita, T.; Phytochemistry' 1977, 16, 1614.

83. Jain, A. C.; Khanna, V. K.; Seshadri, T. R.; Indian J. Chem. 1970, 8, 667.

84. Kaldas M.; Hostettmann, K.; Guillarmod, A. J.; Helvetica Chim. Acta 1975, 58, 2188.

85. Kaldas, M. H.; Guillarmod, A. J.; Phytochemistry 1978, 17, 2083.

86. Kaouadji, M.; Vaillant, I.; Mariotte, A. M.; J. Nat. Prod. 1986, 49, 359.

87. Khvorost, O. P.; Serbin, A. G.; Komissarenko, N. F.; Bublik, N. P.; Kovalev, I. P.; Gordienko, V. G.; Chem. Nat. Compds. 1987, 4, 506.

88. Kitanov, G. M.; Blinova, K. F.; Chem. Nat. Compds. 1987, 2, 151 .

89. Kobayashi, K.; Nishino, C.; Ohya, J.; Sato, S.; Mikawa, T.; Shiobara, Y.; Kodama, M.; J. Antib. 1988, 41, 502.

90. Kobayashi, K.; Nishino, C.; Ohya, J.; Sato, S.; Mikawa, T.; Shiobara, Y.; Kodama, M.; J. Antib. 1988, 41, 741.

91. Kostanecki, V.; Ber. D. Chem. 1892, 25, 1640.

92. Kostanecki, V.; Rutishauser, R.; Ber. D. Chem. 1892, 25, 1648 .

93. Kupchan, S. M.; Streelman, D. R.; Sneden, A. T.; J. Nat. Prod. 1980, 43, 296.

94. Letcher, R. M.; Yue, T. Y.; J. Chem. Soc.; Chem. Comm. 1992, 1310 .

95. Leuckert, C.; Ahmadjian, V.; Culberson, C. F.; Johnson, A.; Mycologia 1990, 82, 370.

96. Lewis, J. R.; Proc. Chem. Soc. 1963, 363, 373.

97. Lin, C. N.; Chung, M. I.; Gan, K. H.; Chiang, J. R.; Phytochemistry 1987, 26, 2381.

98. Lin, C.N.; Liou, S. S.; Ko, F. N.; Teng, C. M.; J. Pharm. Sci. 1992, 81, 1109.

99. Liu, J.; Huang, M.; Zhongcaoyao 1982, 13, 433

100. Locksley, H. D.; Moore, I.; Scheinmann, F.; Tetrahedron 1967, 23, 2229.

101. Locksley, H. D.; Murray, I. G.; J. Chem. Soc.(C) 1970 , 392.

102. Mandal, S.; Chatterjee, A.; Tetrahedron Let. 1987, 28, 1309.

103. Mandal, S.; Das, P. C.; Joshi, P. C.; J. Indian Chem. Soc. 1992, 69, 611.

104. Markham, K. R.; Tetrahedron 1965, 21, 1449.

105. Markham, K. R.; Tetrahedron 1965, 21, 3687.

106. Marston, A.; Hamburger, M.; Diserens, I. S.; Msonthi, J. D.; Hostettmann, K.; Phytochemistry 1993, 33, 809.

107. Massias, M.; Carbonnier, J.; Molho, D.; Phytochemistry 1981, 20, 1577 .

108. Mathis, C. T.; Goldstein, J. H.; Spectrochimica Acta 1964, 20, 871 .

109. McMaster, W. J.; Scott, A. I.; Trippett, S.; J. Chem. Soc. 1960, 4628.

110. Mehta, G.; Shah, S. R.; Venkateswarlu, Y.; Tetrahedron 1994, 50, 11729

111. Meravy, L.; Biol. Plant. 1987, 29, 81.

112. Mesquita, A. A. L.; Correa, D. B.; Gottlieb, O. R.; Magalhães, M. T.; An. Chim. Acta, 1968, 42, 311.

113. Moron, J.; Polonsky, J.; Pourrat, H.; Bull. Soc. Chim. France 1967, 1, 130.

114. Mourão, J. C.; Gottlieb, O. R.; Magalhães, M. T.; An Acad. Brasil. Ciênc. 1966, 38, 435.

115. Neshta, N. M.; Glyzin, V. I.; Nikolaeva, G. G.; Sheichenko, V. I.; Chem. Nat. Compds. 1983, 1, 105.

116. Odontyuya, G.; Purev, O.; Sambuu, D. G.; Nasreen, A.; Atta-Ur, R.; Nat. Prod. Lett. 1995, 5, 269.

117. Oliveira, M. C. F.; Silveira, E. R.; In $18^{\mathrm{a}}$ Reunião Anual da Sociedade Brasileira de Química, Caxambu-MG, 1995.

118. Ortega, E. P.; Garcia, R. E. L.; Rabanal, R. M.; Darias, V.; Valverde, S.; Phytochemistry 1988, 27, 1912.
119. Parra, M.; Picher, M. T.; Seoane, E.; Tortajada, A.; J. Nat. Prod. 1984, 47, 123.

120. Parra, M,; Picher, M. T.; Seoane, E.; Tortajada, A.; J. Nat. Prod. 1985, 48, 998

121. Parra, M.; Seoane, E.; Tortajada, A.; J. Nat. Prod. 1984 47, 868

122. Patel, G. N.; Trivedi, K. N.; Indian J. Chem 1983, 22B, 755.

123. Patel, G. N.; Trivedi, K. N.; Indian J. Chem. 1991, 30B, 437.

124. Patolia, R. J.; Trivedi, K. N.; Indian J. Chem. 1983, $22 B$, 444.

125. Pinto, D. C. G.; Fuzzati, N.; Pazmino, X. C.; Hostettmann, K.; Phytochemistry 1994, 37, 875.

126. Pinto, M. M.; Polonia, J.; Helv. Chim. Acta. 1974, 57, 286.

127. Purev, O.; Odontuya, G.; Oyun, H.; Maksimovna, T. L.; Nasreen, A.; Atta-Ur, R. Nat. Prod. Lett. 1995, 5, 261.

128. Quillinan, A. J.; Scheinmann, F.; J. Chem. Soc. Perkin I 1972, 1382

129. Quillinan, A. J.; Scheinmann, F.; J. Chem. Soc. Perkin I 1973, 1329

130. Rahman, A. U.; Pervin, A.; Feroz, M.; Choudhary, M. I.; Qureshi, M. M.; Perveen, S.; MIR, I.; Khan, M. I.; J. Nat. Prod. 1994, 57, 134.

131. Ravi, P.; Vathani, P.; Reddy, G. C.; Indian J. Het. Chem. 1994, 3, 209.

132. Roberts, J. C.; Chem. Rev. 1961, 61, 591.

133. Ross, D. J.; New Zeland J. Sci. Technol. 1950, 32B, 39.

134. Santesson, J.; Arkiv Kemi 1968, 30, 363.

135. Santesson, J.; Acta Chem. Scand. 1968, 22, 2393.

136. Santesson, J.; Arkiv Kemi 1969, 30, 479.

137. Schainmann, F.; Tetrahedron 1962, 18, 853

138. Shah, G. D.; Shah, R. C.; J. Sci. Industr. Res. 1956, 15B, 630 .

139. Sia, G. L.; Bennett, G. J.; Harrison, L. J.; Sim, K. Y.; Phytochemistry 1995, 38, 1521.

140. Silveira, E. R.; Falcão, M. J. C.; Menezes JR, A.; Kingston, D. G. I.; Glass, T. E.; Phytochemistry 1995, 39, 1433.

141. Simoneau, B.; Brassard, P. A.; J. Chem. Soc. Perkin Trans. I 1984, 1507.

142. Somanathan, R.; Sultanbawa, M. U. S.; J. Chem. SOC. Perkin I 1972, 1935.

143. Stout, G. H.; Balkenhol, W. J.; Tetrahedron 1969, 25, 1947.

144. Stout, G. H.; Christensen, E. N.; Balkenhol, W. J.; Stevens, K. L.; Tetrahedron 1969, 25, 73.

145. Stout, G. H.; Fries, J. L.; Tetrahedron 1969, 25, 5295.

146. Stout, G. H.; Fries, J. L.; Phytochemistry 1970, 9, 235.

147. Sullivan, G.; Stiles, F. D.; Rosler, K. H. A.; J. Pharm. Sci. 1977, 66, 828

148. Sultanbawa, M. U. S. Tetrahedrom 1980, 36, 1465.

149. Sun, H.; Hu, B.; Fan, S.; Ding, J.; Zhiwu Xuebao 1983. 25,460 .

150. Sundholm, E. G.; Tetrahedron 1978, 34, 577.

151. Suzuki,O.; Katsumata, Y.; Oya, M.; Chari, V. M.; Klapfenberger, R.; Wagner, H.; Hostettmann, K.; Planta Medica 1980, 39, 19.

152. Suzuki, O.; Katsumata, Y.; Oya, M.; Chari, V. M.; Vermes, B.; Wagner, H.; Hostettmam, K.; Planta Medica 1981, 42, 17

153. Takagi, S.; Yamari, M.; Yakugaku Zasshi 1982, 102, 546.

154. Tammami, B.; Torrance, S. J.; Fabela, F. V.; Wiedhopf, R. M.; Cole, J. R.; Phytochemistry 1977, 16, 2040.

155. Van Der Sluis, W. G.; Pl. Syst. Evol. 1985, 149, 253.

156. Van Der Sluis, W. G.; Labadie, R. P.; Phytochemistry 1985, 24, 2601.

157. Versluys, C.; Cortes, M.; Lopez, J. T.; Sierra, J. R.: Razmilic, I.; Experientia 1982, 38, 771.

158. Vitale, A. A.; Romanelli, G. P.; Autino, J. C.; Pomilio, A. B.; J. Chem. Res. (S) 1994, 82. 
159. Westerman, P. W.; Gunasekera, S.P.; Sultanhawa, M. U. S.; Kazlauskas, R.; Org. Magn. Reson. 1977, 9, 631

160. Wolfender, J. L.; Hamburger, M.; Msonthi, J. D.; Hostettmann, K.; Phytochemistry 1991, 30, 3625.

161. Wrigley, S. K.; Latif, M. A.; Gibson, T. M.; Robinson, M.
I. C.; Williams, D. H.; Pure \& Appl. Chem. 1994, 66, 2383. 162. Yan-Bin, Y.; Zhou, J.; Yun-nan Chih Wu Yen Chiu 1980, 2, 468.

163. Zhou, H. M.; Liu, Y. L.; Blasko, G.; Cordell, G. A.; Phytochemistry 1989, 28, 3569. 